\title{
POTENSI PANTAI CEMARA, KABUPATEN BANYUWANGI, JAWA TIMUR SEBAGAI KAWASAN EKOWISATA
}

\author{
Agustina Tri Kusuma Dewi ${ }^{\mathrm{a}, *}$, Mega Yuniartik ${ }^{\mathrm{a}}$ \\ ${ }^{a}$ Fakultas Pertanian dan Perikanan, Universitas 17 Agustus 1945 Banyuwangi, Banyuwangi, Indonesia \\ *Koresponden penulis : agustinatdewi@untag-banyuwangi.ac.id
}

\begin{abstract}
Abstrak
Tujuan penelitian ini adalah mengkaji Pantai Cemara, Kabupaten Banyuwangi, Jawa Timur dalam pengembangan Kawasan Ekowisata yang bertanggung jawab dan berkelanjutan. Pendekatan yang digunakan dalam penelitian ini adalah pendekatan deskriptif analitik dengan metode survei. Dari hasil penelitian, terdapat beberapa jenis mangrove, yaitu bakau (Rhizophora mucronata), perepat/ pidada putih/ bogem (Sonneratia alba), dan api-api (Avicennia alba). Asosiasi mangrove sebanyak 3 jenis, yaitu Deruju/ Jeruju (Acanthus ilicifolius L.), Keranji/ Dadap Laut (Clerodendron inerme, dan Kambingan (Derris trifoliata). Selain itu, terdapat dua spesies dari tujuh spesies yang memiliki status dilindungi, yaitu Penyu Hijau (Chelonia mydas) dan Penyu Lekang (Lepidochelys olivacea). Nilai NDVI minimum -0.53 dan maksimum 0.95 yang terdapat pada lokasi penelitian. Nilai parameter fisika dan kimia di Pantai Cemara pun memiliki indikator yang baik sesuai dengan baku mutu. Nilai rat-rata suhu sebesar $28,8{ }^{\circ} \mathrm{C}, \mathrm{pH}$ sebesar 5,1 , oksigen terlarut sebesar $5,5 \mathrm{mg} / \mathrm{L}$, dan amonia sebesar $0,07 \mathrm{mg} / \mathrm{L}$. Parameter tersebut diharapkan dapat menunjang dan memberikan indikator baik dalam mengembangkan sektor ekowisata yang berporoskan antara kawasan konservasi penyu, mangrove, serta pariwisata.
\end{abstract}

Kata Kunci : Ekowisata, Kabupaten Banyuwangi, Mangrove, Penyu, Pantai Cemara

\begin{abstract}
The purpose of this research is to study Cemara Beach, Banyuwangi Regency, East Java in developing responsible and sustainable Ecotourism Areas. The approach used in this study is an analytical descriptive approach with a survey method. From the results of the study, it was found that there are several types of mangrove, namely bakau (Rhizophora mucronata), perepat/ pidada putih/ bogem (Sonneratia alba), dan api-api (Avicennia alba). There are 3 types of mangrove association namely Deruju/ Jeruju (Acanthus ilicifolius L.), Keranji/ Dadap Laut (Clerodendron inerme, dan Kambingan (Derris trifoliata). The other hand, there are two species of seven species that have protected status, namely Green Turtle (Chelonia mydas) and Lekang Turtle (Lepidochelys olivacea). The minimum NDVI value is -0.53 and the maximum is 0.95 found in the study location. The value of physical and chemical parameters at Cemara Beach also has a good indicator in accordance with the quality standard. The average temperature are $28.8^{\circ} \mathrm{C}$, pH are 5.1, dissolved oxygen are $5.5 \mathrm{mg} / \mathrm{L}$, and ammonia are $0.07 \mathrm{mg} / \mathrm{L}$. These parameters are expected to be able to support and provide good indicators in developing the ecotourism sector that trails between turtle conservation areas, mangroves, and tourism.
\end{abstract}

Keywords: ecotourism, Banyuwangi Distric, mangrove, turtle, Cemara beach

\section{PENDAHULUAN}

Pantai Cemara memiliki pasir hitam dengan jajaran pohon cemara di sepanjang pantai. Hal ini merupakan salah satu alternative destinasi baru dekat dengan pusat kota Banyunwangi. Pantai Cemara berlokasi di Dusun Rowo, Desa Pakis, Kecamatan Banyuwangi. Pantai Cemara ini terbagi menjadi dua zona, zona pertama adalah zona untuk pengunjung dan yang kedua adalah zona inti. Pada saat musim penyu bertelur, zona inti inilah yang dipakai dan juga terdapat tempat semi alami untuk bertelur. Lebih dari 16000 pohon cemara terdapat di Pantai Cemara dan lebih dari 5 hektar pohon cemara tumbuh, selain sebagai area konservasi, cemara udang ini berguna untuk menangkal abrasi dan menambah nilai ekonomis bagi wilayah sekitarnya.[2]. 
Mangrove atau tumbuhan bakau adalah vegetasi yang berada di wilayah pasang surut dan dapat ditemukan di sepanjang daerah pesisir tropis hingga subtropis. Indonesia menjadi negara yang memiliki wilayah mangrove terluas di dunia yaitu sekitar 3,1 juta hektar atau $22,6 \%$ dari total mangrove yang ada di dunia [5]. Secara Ekologis, Ekosistem mangrove dapat berfungsi sebagai intrusi air laut, penahan gelombang dan tempat perkembang biakan bagi berbagai jenis hewan, seperti ikan, udang, kepiting, kerang, siput dan hewan lainnya. Selain itu potensi dari mangrove juga bisa sebagai tempat pemijahan (spawning ground), daerah asuhan (nursery ground), dan daerah mencari makan (feeding ground). Hasil hutan mangrove pun dapat dimanfaatkan oleh masyarakat sekitar dalam upaya meningkatkan kondisi ekonomi dan wisata [12].

Sektor wisata sudah sangat lama dikenal sebagai salah satu sector ekonomi yang dapat diandalkan dalam membangun suatu daerah. Hal tersebut karena cakupan kegiatannya sangat luas, memperbesar multiflier effect dalam kesempatan kerja, peluang usaha, dan distribusi pendapatan, sehingga sumbangan ekonomisnya dapat dirasakan oleh masyarakat, pemerintah daerah (pajak/retribusi) maupun pemerintah pusat berupa pajak dan devisa [3].

Ekowisata merupakan salah bentuk dari sector pariwisata yang dapat memberikan beberapa keuntungan baik dari sector ekonomi maupun ekologi. Ekowisata dapat didefinisikan sebagai suatu bentuk perjalanan wisata yang bertanggung jawab terhadap Kawasan alami yang dilakukan dengan tujuan mengkonservasi lingkungan dan melestarikan kehidupan dan kesejahteraan penduduk setempat. Ada enam keuntungan kegiatan ekowisata yaitu : (1) mengurangi ancaman terhadap keanekaragaman hayati yang ada di obyek wisata tersebut; (2) mempromosikan penggunaan sumberdaya alam yang berkelanjutan; (3) membangun konstituensi untuk konservasi secara local, nasional dan internasional; (4) memberikan keuntungan secara langsung dan tidak langsung bagi para stakeholder; (5) menghasilkan keuntungan secara langsung untuk pelestarian lingkungan; (6) memberikan nilai ekonomi dalam kegiatan ekosistem di dalam lingkungan yang dijadikan sebagai objek wisata.[4].

Tujuan penelitian adalah untuk mengidentifikasi potensi dan mengoptimalkan Pantai Cemara sebagai Kawasan Ekowisata yang terdapat di Banyuwangi.

\section{MATERI DAN METODE}

\section{Lokasi Penelitian}

Penelitian dilakukan di Kawasan Mangrove Pantai Cemara yang berada di Dusun Rowo, Desa Pakis, Kecamatan Banyuwangi, Kabupaten Banyuwangi. Transek 1. $8^{\circ} 16,303^{\prime} \mathrm{S} ; 114^{\circ} 22,019^{\prime} \mathrm{T}$, Transek 2. $8^{\circ} 16,364^{\prime} \mathrm{T} ; 114^{\circ} 22,011^{\prime} \mathrm{T}$, Transek 3 . $8^{\circ} 16,324$ 'S; $\quad 114^{\circ} 21,885^{\prime} \mathrm{T}, \quad$ Transek 4. $8^{\circ} 16,131$ 'S; $\quad 114^{\circ} 22,180^{\prime} \mathrm{T}$, Transek 5 . $8^{\circ} 16,036$ 'S; $114^{\circ} 22,253^{\prime} \mathrm{T}$, Transek 6 . $8^{\circ} 15,917 ' \mathrm{~S} ; 1^{\circ} 4^{\circ} 22,349^{\prime} \mathrm{T}$, dan Transek 7 . $8^{\circ} 15,720^{\prime} \mathrm{S} ; 114^{\circ} 22,439^{\prime} \mathrm{T}$. Peta lokasi penelitian dapat dilihat pada Gambar 1.

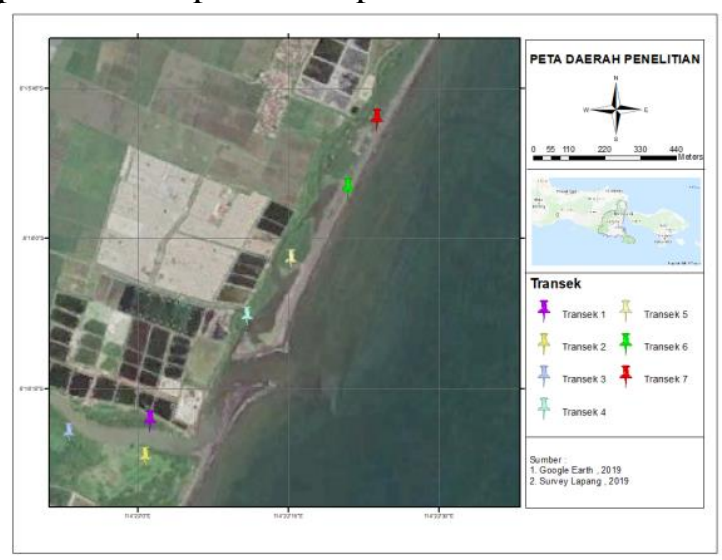

Gambar 1. Peta lokasi penelitian

\section{Pengambilan Sampel Mangrove}

Pengambilan sampel dilaksanakan mulai tanggal 7-17 April 2019. Pendekatan yang digunakan dalam penelitian adalah pendekatan deskriptif analitik dengan metode survei, yaitu dengan sensus dan survei sampel.

Pengambilan sampel dalam penelitian ini merupakan sampel wilayah. Sampel wilayah meliputi zonasi yang berada pada kawasan 
mangrove menggunakan transek kuadrat dengan ukuran 5 x $5 \mathrm{~m}$ dengan jumlah 4 buah atau 8 transek. Metode transek adalah jalur sempit melintang pada lahan yang akan dipelajari atau diselidiki dengan tujuan mengetahui hubungan perubahan vegetasi dan perubahan lingkungan atau untuk mengetahui jenis vegetasi yang ada di suatu lahan secara tepat. [5]. Sampel mangrove yang diambil adalah sampel daun, buah, dan bunga. Selanjutnya, dilakukan identifikasi jenis di Laboratorium Perikanan Universitas 17 Agustus 1945 Banyuwangi, dengan mengamati kesamaan morfologi sampel. Buku Identifikasi dengan menggunakan 'Buku Panduan Mangrove di Indonesia'.[6].

Pemanfaatan mangrove di Pantai Cemara sebagai wilayah ekowisata ditanamkan pada masyarakat sekitar melalui beberapa langkah, pertama adalah membuat suatu komunitas pelestarian mangrove dan habitat sekitarnya agar dapat dimanfaatkan dan menjadi nilai lebih baik dari segi ekologis dan ekonomis.

\section{Indeks Vegetasi/Normalized Difference Vegetation Index}

NDVI atau sering disebut Indeks Vegetasi adalah kombinasi matematis antara band red dan NIR yang telah lama digunakan untuk mengidentifikasi keberadaan dan kondisi vegetasi [10].

NDVI memiliki rentang nilai -1 sampai dengan 1. Metode skala lanskap (NDVI) adalah metode yang memperhitungkan besaran nilai kehijauan vegetasi yang diperoleh dari pengolahan sinyal digital data nilai kecerahan (brightness) beberapa kanal data sensor satelit dari citra satelit. Citra yang digunakan adalah citra satelit Sentinel 2 A.

Untuk menghitung nilai kerapatan hutan mangrove digunakan metode rasio band Inframerah dekat (NIR) dan band merah dengan formula :

$$
N D V I=\frac{(\mathrm{NIR}-\mathrm{red})}{(\mathrm{NIR}+\mathrm{red})}
$$

Nilai NDVI berkisar dari -1 dengan 1 dimana klasifikasi -1 sampai 0 termasuk ke dalam kelompok bukan vegetasi dan 0 sampai dengan 1 termasuk kelompok vegetasi.

\section{Analisis SWOT}

Metode yang digunakan untuk menentukan strategi pengembangan dalam mengoptimalkan kawasan Ekowisata dari faktor kekuatan, peluang, kelemahan dan ancaman terhadap kondisi yang ada pada Kawasan ekowisata di Pantai Cemara.

\section{HASIL DAN PEMBAHASAN}

\section{Potensi Pantai Cemara}

Pada tahun 2011 lalu Pemerintah Banyuwangi bersama dengan masyarakat sekitar melakukan kegiatan penanaman bibit tanaman Cemara Udang (Casuarina equisetifolia) sebanyak 19 ribu bibit di sepanjang pantai yang memiliki luas 10.2 hektar. Dan pada tahun 2017 , masyarakat Sekitar secara mandiri kembali melakukan penanaman bibit tanaman Cemara Udang sebanyak seribu butir sehingga wilayah tersebut menjadi Kawasan Konservasi Hutan Cemara dengan berbagai macam tumbuhan bakau atau mangrove.

\subsection{Mangrove}

Berdasarkan hasil penelitian dan diolah menggunakan perangkat GIS, didapatkan bahwa luasan wilayah mangrove pada lokasi penelitian adalah $305.631,9 \mathrm{~m}^{2}$. 


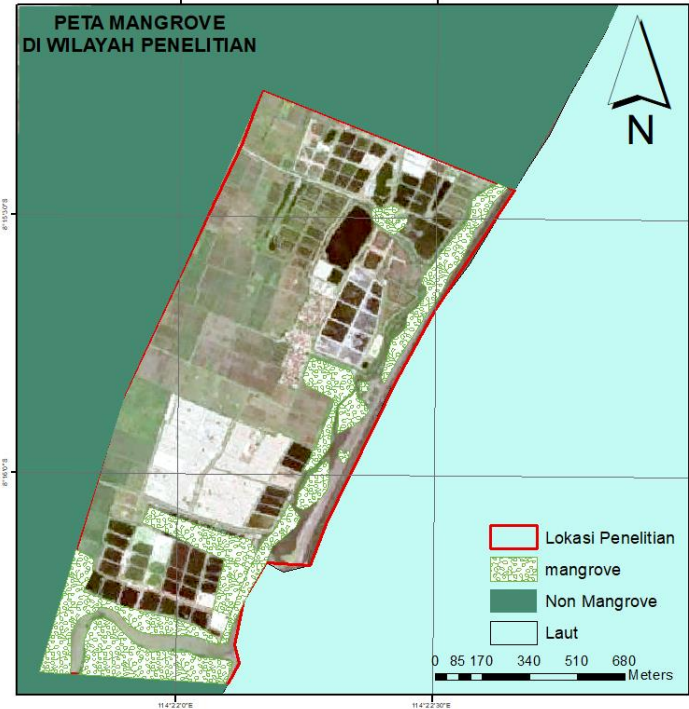

Gambar 2. Peta persebaran mangrove wilayah penelitian

Jenis mangrove yang terdapat di Pantai Cemara ada 3 jenis, yaitu bakau (Rhizophora mucronata), perepat/ pidada putih/ bogem (Sonneratia alba), dan api-api (Avicennia alba). Selanjutnya, terdapat asosiasi mangrove sebanyak 3 jenis, yaitu Deruju/ Jeruju (Acanthus ilicifolius L.), Keranji/ Dadap Laut (Clerodendron inerme, dan Kambingan (Derris trifoliata). Data spesies mangrove pada transek dapat dilihat pada Tabel 1 .

Tabel 1. Spesies mangrove pada transek penelitian

\begin{tabular}{lll}
\hline No. Dokumentasi & Jenis Mangrove \\
\hline 1. & $\begin{array}{l}\text { Mangrove } \\
\text { (Rhizophora } \\
\text { mucronata) }\end{array}$ \\
2. & $\begin{array}{l}\text { Api-api } \\
\text { (Avecennia alba) }\end{array}$ \\
Asosiasi Mangrove & $\begin{array}{l}\text { Perepat, pidada } \\
\text { putih, bogem } \\
\text { (Sonneratia alba) }\end{array}$ \\
\hline
\end{tabular}

\begin{tabular}{l}
\hline 1. \\
$\begin{array}{l}\text { Deruju/ Jeruju } \\
(\text { Acanthus } \\
\text { ilicifolius } \text { L.). }\end{array}$ \\
$\begin{array}{l}\text { Kambingan } \\
\text { (Derris trifoliata) }\end{array}$ \\
\hline
\end{tabular}

Berdasarkan tabel pengamatan parameter fisika dan kimia (Tabel 2), suhu rata-rata perairan transek $1-7$ yang berada di wilayah sekitar Pantai Cemara adalah $28,9{ }^{\circ} \mathrm{C}$ yang mana nilai ini masih termasuk ke dalam tingkat sangat wajar, karena pada umumnya kisaran suhu suatu permukaan laut pada daerah perairan indonesia berada pada 26$31,5{ }^{\circ} \mathrm{C}$ [10]. Pertumbuhan dan kehidupan biota air sangat dipengaruhi suhu air, suhu optimal bagi kehidupan ikan dan biota air di perairan tropis berkisar antara $28-32{ }^{\circ} \mathrm{C}$ [6]. Berhubungan dengan ekowisata bahari, dalam Keputusan Menteri Lingkungan Hidup 2004 juga tercantum baku mutu suhu secara alami yang menyatakan kondisi normal suhu lingkungan, bervariasi setiap saat. Selain itu diperbolehkan terjadi perubahan sampai dengan $<2{ }^{\circ} \mathrm{C}$ dari suhu alami tersebut, sehingga dapat dikatakan suhu perairan di sekitar Pantai Cemara masih tergolong baik.

Tabel 2. Parameter fisika dan kimia lokasi penelitian

\begin{tabular}{llc}
\hline No. & \multicolumn{1}{c}{ Parameter } & Rerata \pm SD \\
\hline 1. & Suhu $(\mathrm{C})$ & $28,9 \pm 2,11$ \\
2. & pH & $5,1 \pm 1,35$ \\
3. & DO $(\mathrm{mg} / \mathrm{L})$ & $5,5 \pm 0,78$ \\
4. & Amonia $(\mathrm{mg} / \mathrm{L})$ & $0,1 \pm 0,13$ \\
5. & Nitrit $(\mathrm{mg} / \mathrm{L})$ & $0,1 \pm 0,08$ \\
6. & Nitrat $(\mathrm{mg} / \mathrm{L})$ & $1,8 \pm 2,37$ \\
7. & Salinitas $(\mathrm{ppt})$ & $5,4 \pm 4,35$ \\
\hline
\end{tabular}

Nilai pH berada pada angka 4 - 7 dengan rata-rata yang terukur pada transek $1-7$ adalah 5,1. Nilai ini masih termasuk dalam 
kategori baik karena baku mutu $\mathrm{pH}$ untuk wisata bahari sebesar $7-8.5$ dengan perubahan sampai dengan $<0.2$ satuan $\mathrm{pH}$.

Oksigen terlarut atau Dissolved Oxygen transek 1- 7 yang berada pada sekitar Pantai Cemara bekisar antara 4,7 - 6,5 dengan ratarata 5,5. Nilai tersebut sangat bagus untuk pengembangan wisata bahari maupun kehidupan biota laut sekitar Pantai Cemara. Baku mutu DO untuk kehidupan biota laut dan juga wisata bahari memiliki nilai yang sama, yaitu $>5 \mathrm{mg} / \mathrm{L}$.

Kandungan amonia yang berada pada transek 1 - 7 di sekitar Pantai Cemara masih dalam kategori bagus karena berdasarkan Keputusan Menteri Lingkungan Hidup Tahun 2004 mengenai Baku Mutu Air Laut untuk Biota Laut adalah sebesar 0.1 untuk amonia total, dan untuk kadar nitrat yang berada di lokasi penelitian terhitung tinggi karena Baku Mutu yang tertulis adalah 0,008.

Nilai salinitas berkisar pada angka 0 - 11 dengan rata-rata 5,4. Terlihat dari hasil tiap transek terlihat bahwa transek 3 memiliki tingkat salinitas paling tinggi di antara transek lainnya.

\subsection{Indeks Vegetasi/Normalized Difference Vegetation Index}

Nilai yang mewakili vegetasi berada pada rentang 0.1 sampai dengan 0.7 , jadi jika nilai $N D V I$ di atas nilai tersebut maka menunjukkan tingkat kesehatan dari tutupan vegetasi yang lebih baik. [10]. Pada penelitian ini, hasil kalkulasi NDVI dari aplikasi snap dan acrmap dihasilkan nilai $N D V I$ minimum adalah - 0,53 dan maksimum 0,95 (dapat dilihat pada Gambar. 3). Dari hasil tersebut diklasifikasi menjadi tiga kelas kerapatan tajuk, yaitu : Jarang $(0,01-0.25)$, Sedang $(0,25-0,5)$, Lebat $(0,5-1)$ yang mana hasil akhirnya adalah nilai pada lokasi penelitian termasuk kategori sedang dan lebat.



Gambar 3. Hasil NDVI Pantai Cemara

\section{Potensi Lain}

Dari hasil Pengamatan survei dalam mengidentifikasi potensi didapat hasil, pada lahan seluas kurang lebih 5 hektar ditumbuhi beberapa spesies mangrove dan dihuni oleh berbagai macam habitat. Ciri khas yang terdapat pada Pantai Cemara ini adalah banyaknya Pohon Cemara laut dan menjadi salah satu wilayah untuk penyu bertelur sehingga telah dibuat tempat semi alami guna melakukan langkah konservasi terhadap spesies penyu tersebut.

Dari data pemerintah setempat, angka kehidupan penyu yang berada di Kawasan konservasi Pantai Cemara ini adalah $80 \%$ dan pada tahun 2017 terdapat sekitar 58 sarang dengan lebih dari 5 ribu telur yang berhasil menetas dan dilepaskan kembali ke habitatnya.

Menurut IUCN Red List of Threatened Species (Daftar Merah Spesies Yang Terancam Punah) sebanyak tujuh penyu di dunia. Diantaranya adalah Penyu hijau (Chelonia mydas), Penyu sisik (Eretmochelys imbricata), Penyu Kemp's ridley (Lepidochely skempi), Penyu lekang (Lepidochely solivacea), Penyu belimbing (Dermochelys coriacea), Penyu pipih (Natator depressus), dan Penyu tempayan (Caretta caretta) Dan terdapat dua spesies penyu yang terdapat di Pantai Cemara, yaitu 
Penyu Hijau (Chelonia mydas) dan Penyu Lekang (Lepidochely solivacea) Penyu berperan penting dalam mengatur struktur habitat mereka. Selain itu penyu dan telurnya juga dapat menjadi sumber makanan bagi banyak spesies, bahkan penyu juga dapat membantu penyebaran berbagai benih tanaman.

\section{Strategi Pengembangan Ekowisata}

Strategi pengembangan ekowisata dirumuskan melalui analisis SWOT yang meliputi lingkungan internal dan lingkungan eksternal. Untuk lebih jelasnya dapat diuraikan sebagai berikut :

\section{a. Kekuatan}

1. Keragaman mangrove dan Penyu yang terdapat di kawasan Pantai Cemara

2. Pemandangan Alam di Kawasan Panati Cemara

3. Salah Satu obyek wisata alam alternatif di Kabupaten Banyuwangi

b. Kelemahan

1. Kurang tersedianya Pemandu wisata dalam kegiatan ekowisata

2. Belum tersedianya sarana dan prasarana penunjang kegiatan wisata (Listrik, Jaringan Air Minum dan Kamar Mandi)

3. Kurangnya pemahaman masyarakat dan penunjang tentang ekowisata

c. Peluang

1. Dikembangkan wisata telusur sungau menggunakan sampan atau kano dengan menyajikan pemandangan mangrove

2. Pengelolaan hasil mangrove menjadi sirup, teh, peyek dan kopi mangrove

3. Kerjasama dengan TK, SD, SMP, SMA mengenai tujuan field trip ke Pantai Cemara adalah sebagai pusat edukasi penyu, mangrove dan cemara.

d. Ancaman

1. Dampak negatif dari kegiatan wisata (sampah kegiatan yang merusak mangrove dll).

2. Degradasi tutupan mangrove akibat buangan limbah dan ditebangi masyarakat.

3. Persaingan dengan obyek wisata lain.
Berdasarkan hasil analisis lingkungan internal dan eksternal di atas, maka digunakan matriks analisis untuk mengetahui strategi untuk mengoptimalkan kawasan wisata di Pantai Cemara. Untuk lebih jelas disajikan pada Tabel 3 berikut :

Tabel 3. Grand strategy pengembangan kawasan ekowisata Pantai Cemara

\begin{tabular}{|c|c|c|}
\hline EFAS/IFAS & $\begin{array}{l}\text { STRENGETHS } \\
\text { (S) }\end{array}$ & $\begin{array}{l}\text { WEAKNESSSE } \\
\text { S (W) }\end{array}$ \\
\hline $\begin{array}{l}\text { OPPOTUNITI } \\
\text { ES }(\mathrm{O})\end{array}$ & $\begin{array}{l}\frac{\text { Strategi S-O }}{\text { Mengembangkan }} \\
\text { kegiatann } \\
\text { konservasi dan } \\
\text { rehabilitasi } \\
\text { mangrove } \\
\text { sebagai salah } \\
\text { satu program } \\
\text { wisata }\end{array}$ & $\begin{array}{l}\text { Strategi W-O } \\
\text { Meningkatkan } \\
\text { Partisipasi dan } \\
\text { pemberdayaan } \\
\text { masyarakat } \\
\text { wisata }\end{array}$ \\
\hline THREATS (T) & $\begin{array}{l}\text { Strategi S-T } \\
\text { Pengelolaan dan } \\
\text { pengaturan } \\
\text { ekowisata Pantai } \\
\text { Cemara dengan } \\
\text { sistem yang } \\
\text { berkelanjutan } \\
\text { (sustainable } \\
\text { system) }\end{array}$ & $\begin{array}{l}\text { Strategi W-T } \\
\text { Penguatan } \\
\text { konsep } \\
\text { ecotourism }\end{array}$ \\
\hline
\end{tabular}

Berdasarkan analisis diatas diperoleh 4 alternatif strategi pengembangan untuk mengoptimalkan kawasan wisata di Pantai Cemara, sebagai berikut :

1. Mengembangkan Kegiatan konservasi dan rehabilitasi sebagai salah satu program wisata. Hal-hal yang dapat dilakukan dengan berbagai aktivitas yang ramah lingkungan secara berkelanjutan, seperti monitoring pasca penanaman mangrove, menjaga kebersihan serta pemanduan terhadap wisatawan yang datang.

2. Meningkatkan partisipasi dan pemberdaayan masyarakat wisata. Konsep pengembangan ekowisata salah satunya adalah bertujuan untuk meningkatkan partisipasi masyarakat dalam pengelolaan, sehingga dapat bermanfaat untuk ekonomi masyarakat setempat. Adanya programprogram pemberdayaan masyarakat yang ada sudah sepatutnya makin dikembangkan dan semakin diaktifkan. Selain itu, perlu 
dikembangkan lagi partisipasi masyarakat untuk menjadi pemandu wisata. Pengelolaan berbasis masyarakat merupakan salah satu pendekatan pengelolaan alam yang meletakkan pengetahuan dan kesadaran lingkungan masyarakat lokal sebagai dasar pengelolaannya.

3. Pengelolaan dan Pengaturan Ekowisata Pantai Cemara dengan sistem yang berkelanjutan (sustainable system)

4. Penguatan Konsep Ecotourism. Konsep ecotourism yang sesuai akan meminimalkan dampak negatif terhadap kerusakan lingkungan. Konsep ekowisata berorientasi pada keseimbangan antara wisata dengan kepentingan perlindungan sumberdaya a/lingkungan (konservasi) dengan menggunakan sumberdaya dan mengikutsertakan masyarakat lokal.

\section{KESIMPULAN}

Ekowisata bahari cukup berpotensi dikembangkan di daerah Pantai Cemara, Kabupaten Banyuwangi. Seperti kita ketahui, terdapat dua spesies penyu dengan berstatus dilindungi yaitu Penyu Hijau (Chelonia mydas) dan Penyu Lekang (Lepidochely $s$ olivacea) serta kawasan mangrove yang beragam seperti bakau (Rhizophora mucronata), perepat/ pidada putih/ bogem (Sonneratia alba), dan api-api (Avicennia alba). Selanjutnya, terdapat asosiasi mangrove, yaitu Deruju/ Jeruju (Acanthus ilicifolius L.), Keranji/ Dadap Laut (Clerodendron inerme, dan Kambingan (Derris trifoliata). Parameter fisika dan kimia yang didapatkan dari wilayah sekitar Pantai Cemara pun memiliki indikator baik sesuai dengan baku muku yang ada.

Strategi Pengembangan untuk mengoptimalkan kawasan wisata pantai cemara dapat dilakukan dengan mengembangkan berbagai kegiatan konservasi dan rehabilitasi mangrove sebagai salah satu program wisatanya, dan meningkatkan Partisipasi dan Pemberdayaan Masayarakat sekitar. Oleh karena itu, sudah seharusnya menjadi tanggung jawab bersama dan memiliki kesadaran serta tekad secara seluruh lapisan masyarakat bersama stakeholder baik pemerintah maupun swasta bahu membahu memajukan ekowisata pedesaan yang berbasis wilayah konservasi.

\section{UCAPAN TERIMAKASIH}

Para penulis mengucapkan terimakasih kepada Kementerian Riset, Teknologi, dan Pendidikan Tinggi Republik Indonesia atas dorongan dan dukungan keuangan untuk menyelesaikan penelitian kami

\section{DAFTAR PUSTAKA}

[1] BSN [Badan Standardisasi Nasional]. (2010). Basis data spasial oseanografi: suhu salinitas, oksigen terlarut, derajat keasaman, turbiditas, dan kecerahan. Rancangan Standar Nasional Indonesia 3. 7644: 2010. $17 \mathrm{hlm}$.

[2] BPS [Badan Pusat Statistik]. 2009. Banyuwangi dalam angka.

[3] Damanik, Jani anton dan Helmut F. Weber. 2006. Perencanaan Ekowisata: Dari Teori keAplikasi, Yogyakarta: PUSPAR UGM dan Penerbit Andi.

[4] Drumm, et al. 2002. Ecotourism Development. AN Introduction to Ecotourism Planning. The Nature Conservancy. Arlington. USA.

[5] Giri, C., Ochieng, E., Tieszen, L.L., Zhu, Z., Singh, A., Loveland, T., Masek, J. and Duke, N., 2011. Status and distribution of mangrove forests of the world using earth observation satellite data. Global Ecology and Biogeography, 20(1), pp. $154-159$.

[5] Fachrul, M. F., 2007. Metode Sampling Bioekologi. Bumi Aksara, Jakarta. 
[6] Kementerian Lingkungan Hidup. (2004). Surat Keputusan Menteri Negara Lingkungan Hidup Nomor: 51 Tahun 2004 tentang Baku Mutu Air Laut untuk Wisata Bahari dan Biota Laut. Jakarta.

[7] Kitamura, S., C. Anwar., A. Chaniago., dan S. Baba. 1997. Buku Panduan Mangrove di Indonesia. International Society For Mangrove Ecosystems (ISME): Bali.

[8] Kordi, M.G.H.K. dan A. B. Tancung. (2007). Pengelolaan Kualitas Air dalam Budi Daya Perairan. Penerbit: Rineka Cipta. Cetakan pertama. Hal 58. Jakarta.

[9] Kustanti, A. 2011. Manajemen Hutan Mangrove. Bogor: Institut Pertanian Bogor Press.
[10] Lillesand T.M， W.R. Kiefer. 1990. Penginderaan Jauh dan Interpretasi Citra. Yogyakarta: Gadjah Mada University Press.

[11] Prahasta. 2008. "Konsep-konsep Sistem Informasi Geografis. Teknik Informatika. Universitas Negeri Malang.

[12] Sudiarta, Made. 2006. Ekowisata Hutan Mangrove : Wahana Pelestarian Alam Dan Pendidikan Lingkungan. Jurnal Manajemen Pariwisata, Juni 2006, volume 5 , nomor 12

[13] Syaifullah, M. D. (2015). Suhu Permukaan Laut Perairan Indonesia dan Hubungannya dengan Pemanasan Global. Jurnal Segara. 11(2), 103-113. 